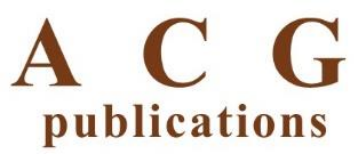

Rec. Nat. Prod. 14:3 (2020) 190-195

\title{
Diterpenoids and Sesquiterpenoids from Syzygium fluviatile
}

\author{
Dingli Zhang $\odot$, Yikao Hu $\odot{ }^{1}$, Li Wang ${ }^{\oplus}$, Shengxiong Huang ${ }^{-2}$, \\ Yan Zhao $\oplus^{-}$, Mengjia $\mathrm{Li} \oplus^{1}$, Feng $\mathrm{Li}^{\oplus}{ }^{1}$ and Yong Zhao ${ }^{1, *}$ \\ ${ }^{I}$ College of Chemistry and Chemical Engineering, Yunnan Normal University, Kunming 650500, \\ China \\ ${ }^{2}$ State Key Laboratory of Phytochemistry and Plant Resources in West China, Kunming Institute of \\ Botany, Chinese Academy of Sciences, Kunming 650201, China
}

(Received August 30, 2019; Revised October 26, 2019; October 27, 2019)

\begin{abstract}
A new monocyclic diterpenoid, cassipouryl formate, (1) together with three known diterpenoids (2-4) and five known sesquiterpenoids (5-9) were isolated from the twigs and leaves of Syzygium fluviatile. The new isolate was elucidated by various spectroscopic technologies. This was the first example of the chemical constituents from this species and the first report on the diterpenoids from genus Syzygium.
\end{abstract}

Keywords: Syzygium fluviatile; Myrtaceae; diterpenoids; sesquiterpenoids.. (C) 2020 ACG Publications. All rights reserved.

\section{Introduction}

The genus Syzygium is one of the largest groups of the family Myrtaceae with more than 500 species distributed in the tropic and subtropical regions of the world [1]. Many of them have been used as an important crude drug for the treatment of diabetes in Southeast Asian nations [2]. Previous phytochemical research on Syzygium demonstrated that flavonoids, hydrolysable tannins, phenylpropanoids, chromone derivatives, phloroglucinol derivatives, and triterpenes were their major constituents [1, 3-7]. Syzygium fluviatile (Hemsl.) Merr. et Perry, is a shrub which distributed in Guangdong and Guangxi Province in China [8]. As far as we know, there has not report on the chemical constituents of this plant to date. In our interest in the discovery of bioactive metabolites from Syzygium plants, one new monocyclic diterpenoid, (1) together with three known diterpenoids (2-4) and five known sesquiterpenoids (5-9) (Figure 1) were isolated from the twigs and leaves of this species.

\footnotetext{
* Corresponding author: zhaooy@126.com; Phone: 86-871-65941087 Fax: 86-871-65941088 


\section{Materials and Methods}

\subsection{Plant Material}

The twigs and leaves of Syzygium fluviatile (Hemsl.) Merr. et Perry were collected in November 2016 from Xishuang Banna Tropical Botanical Garden, P. R. China, and were authenticated by Prof. Yu Chen at Kunming Institute of Botany, Chinese Academy of Science. Plant specimens (CEYNNU 20161102) were deposited at College of Chemistry and Chemical Engineering, Yunnan Normal University.

\subsection{Extraction and Isolation}

The air-dried and powdered twigs and leaves of $S$. fluviatile $(5.0 \mathrm{~kg})$ were extracted with $70 \%$ acetone $(8 \mathrm{~L} \times 3)$ at room temperature, then evaporated under reduced pressure to provide a residue. the residue was divided with petroleum ether $(4 \times 1 \mathrm{~L})$, EtOAc $(4 \times 1 \mathrm{~L})$, and n-BuOH $(4 \times 1 \mathrm{~L})$, sequentially into three parts. The EtOAc extract $(120 \mathrm{~g})$ was subjected to silica gel column chromatography (CC) using a gradient system of petroleum ether/acetone (v/v, 50:0 to 0:1) to afford ten fractions (Fr A-J).

Fraction A $(0.6 \mathrm{~g})$ was further chromatographed over silica gel $\mathrm{CC}$ using a gradient elution of petroleum ether/ethyl acetate (v/v, 20:1-5:1) to afford three subfractions Fr A1-A4, then fraction A2 (70 mg) was isolated by Sephadex $\mathrm{LH}-20$ column $\left(\mathrm{CHCl}_{3} / \mathrm{MeOH}, 1: 1\right)$, followed by semipreparative $\operatorname{HPLC}\left(\mathrm{MeOH} / \mathrm{H}_{2} \mathrm{O} 95: 5\right)$ to give compounds $4\left(1.5 \mathrm{mg}, t_{\mathrm{R}}=16 \mathrm{~min}\right)$ and $7\left(2.5 \mathrm{mg}, t_{\mathrm{R}}=22 \mathrm{~min}\right)$. The Sephadex LH-20 column $\left(\mathrm{CHCl}_{3} / \mathrm{MeOH}, 3: 2\right)$ chromatography for fraction $\mathrm{D}(2.1 \mathrm{~g})$, followed by silica gel CC with petroleum ether/ethyl acetate (v/v, 20:1) give four subfractions Fr D1-D4. The purification of fraction D3 $(0.5 \mathrm{~g})$ with Sephadex LH-20 column $\left(\mathrm{CHCl}_{3} / \mathrm{MeOH}, 1: 1\right)$ and semipreparative HPLC $\left(\mathrm{MeOH} / \mathrm{H}_{2} \mathrm{O} 93: 7\right)$ to give compounds $1\left(1.0 \mathrm{mg}, t_{\mathrm{R}}=15 \mathrm{~min}\right)$ and $2(1.5 \mathrm{mg}$, $\left.t_{\mathrm{R}}=12 \mathrm{~min}\right)$. Fraction E (4.0 g) was decolorized by MCI gel $\left(\mathrm{MeOH} / \mathrm{H}_{2} \mathrm{O} 95: 5\right)$, then treated with silica gel CC using petroleum ether/ethyl acetate (v/v, 5:1) to provide three subfractions Fr E1-E3. Fraction E2 $(0.7 \mathrm{~g})$ afforded compounds $6\left(1.6 \mathrm{mg}, t_{\mathrm{R}}=11 \mathrm{~min}\right), \mathbf{8}\left(1.5 \mathrm{mg}, t_{\mathrm{R}}=15 \mathrm{~min}\right)$, and $\mathbf{9}(1.2$ $\left.\mathrm{mg}, t_{\mathrm{R}}=17 \mathrm{~min}\right)$ by Sephadex LH-20 chromatography $\left(\mathrm{CHCl}_{3} / \mathrm{MeOH}, 3: 2\right)$ and semipreparative HPLC $\left(\mathrm{MeOH} / \mathrm{H}_{2} \mathrm{O}\right.$ 92:8). Fraction I (2.9 g) was decolorized in the same way, followed by chromatograhy over silica gel CC with petroleum ether/ethyl acetate (v/v, 10:1) to yield five subfractions Fr I1-I5. Sephadex LH-20 column $\left(\mathrm{CHCl}_{3} / \mathrm{MeOH}, 3: 2\right)$ separation of fraction I4 $(0.3 \mathrm{~g})$ along with the semipreparative HPLC $\left(\mathrm{MeOH} / \mathrm{H}_{2} \mathrm{O} 90: 10\right)$ led to compounds $3\left(1.5 \mathrm{mg}, t_{\mathrm{R}}=20 \mathrm{~min}\right)$ and $\mathbf{5}(1.0 \mathrm{mg}$, $\left.t_{\mathrm{R}}=15 \mathrm{~min}\right)$.

\section{Results and Discussion}

Compound $\mathbf{1}$, a colorless gum $\left(\mathrm{CH}_{3} \mathrm{OH}\right)$, of which molecular formula was determined as $\mathrm{C}_{21} \mathrm{H}_{38} \mathrm{O}_{2}$ by positive HR-EI-MS ( $\mathrm{m} / \mathrm{z} 322.2878[\mathrm{M}]^{+}$, calc. 322.2872), requiring 3 degrees of unsaturation. Strong UV absorption at $197 \mathrm{~nm}$ implied it had isolated chromophores. IR spectrum disclosed the existence of ester carbonyl $\left(1731 \mathrm{~cm}^{-1}\right)$ and olefinic bond $\left(1639 \mathrm{~cm}^{-1}\right)$. One olefinic methine at $\delta_{\mathrm{H}} 5.36(1 \mathrm{H}, \mathrm{td}, J=7.2,0.8 \mathrm{~Hz})$, one oxymethylene at $\delta_{\mathrm{H}} 4.68(2 \mathrm{H}, \mathrm{d}, J=7.1 \mathrm{~Hz})$, one formyl group at $\delta_{\mathrm{H}} 8.07(1 \mathrm{H}, \mathrm{s})$, two tertiary methyl at $\delta_{\mathrm{H}} 0.85(3 \mathrm{H}, \mathrm{d}, J=6.6 \mathrm{~Hz})$ and $\delta_{\mathrm{H}} 0.84(3 \mathrm{H}, \mathrm{d}$, $J=6.6 \mathrm{~Hz})$, three quaternary methyls $\left(\delta_{\mathrm{H}} 0.86, \mathrm{~s} ; 0.87\right.$, s; and $\left.1.71, \mathrm{~s}\right)$ including one bearing $s p^{2}$ one were observed in the ${ }^{1} \mathrm{H}$ NMR. The ${ }^{13} \mathrm{C}$ NMR spectra demonstrated 21 carbon signals covering a formyl carbon $\left(\delta_{\mathrm{C}} 161.1\right)$, two olefinic ones $\left(\delta_{\mathrm{C}} 143.8\right.$, and 117.3), five methyls $\left(\delta_{\mathrm{C}} 22.7,22.6,19.8\right.$, 19.7, and 16.4), nine methylenes $\left(\delta_{\mathrm{C}} 24.8-60.8\right)$ including one oxidized, three $s p^{3}$ methines $\left(\delta_{\mathrm{C}} 27.9\right.$, 32.7 and 32.8), and one $s p^{3}$ quaternary carbon. Considering of 3 degrees of unsaturation these evidences unambiguously disclosed that it was a formate of monocyclic diterpenoid. All the NMR data of 1 were closely similar to those of the known compound 2, cassipourol [9], except for the only difference of a formyloxy at C-15 in $\mathbf{1}$ instead of a hydroxyl in cassipourol. This hypothesis was 
supported by the HMBC cross peaks (as Figure 2$)$ between $\mathrm{H}-1{ }^{\prime}\left(\delta_{\mathrm{H}} 8.07\right)$ and $\mathrm{C}-15\left(\delta_{\mathrm{C}} 60.8\right)$, and between $\mathrm{H}-15\left(\delta_{\mathrm{H}} 4.68\right)$ and C-13 $\left(\delta_{\mathrm{C}} 143.8\right), \mathrm{C}-14\left(\delta_{\mathrm{C}} 117.3\right)$ and C-1' $\left(\delta_{\mathrm{C}} 161.1\right)$.<smiles>CC(=CCOC=O)CCCC(C)CC[C@H]1[C@@H](C)CCC[C@]1(C)I</smiles><smiles>C/C(=C\CO)CCCC(C)CC[C@H]1[C@@H](C)CCCC1(C)C</smiles><smiles>[3H]C(C)CCC[C@H](C)CCC[C@@H](C)CCC/C(C)=C/C(I)OC(=O)CCC1=C(C)C(=O)NC(=O)[C@@H]1C</smiles>

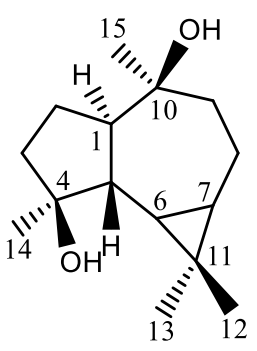

5

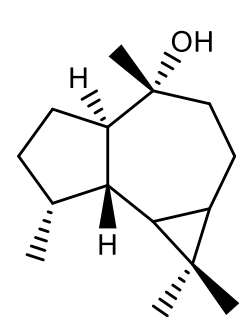

6

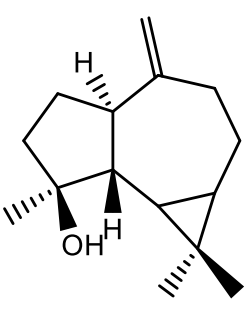

7<smiles>CC1=CC2C=CCC[C@@H](C)C2[C@@H](I)C1</smiles>

8<smiles>CC(C)[C@H]1CC[C@@H](O)[C@H]2CC[C@@H](C)C[C@@H]21</smiles>

9

Figure 1. The chemical structures of compounds 1-9

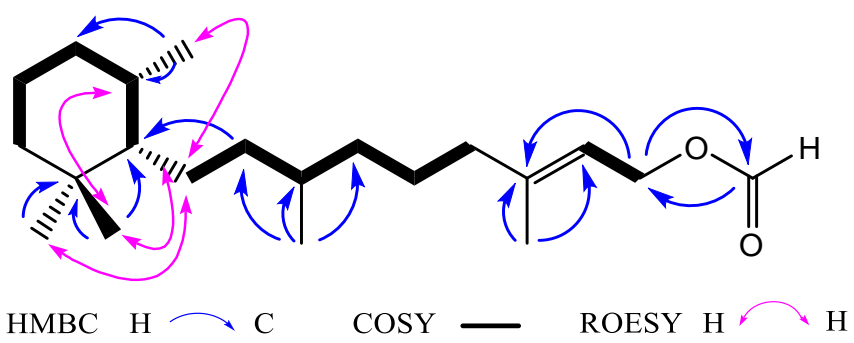

Figure 2. Key 2D NMR correlations of 1

Further HMBC correlations combing with the ${ }^{1} \mathrm{H}-{ }^{1} \mathrm{H}$ COSY correlations (Figure 2) of $\mathrm{H}-2 / \mathrm{H}-$ $3 / \mathrm{H}-4 / \mathrm{H}-5 / \mathrm{H}-6$, of $\mathrm{H}-7 / \mathrm{H}-8 / \mathrm{H}-9 / \mathrm{H}-10 / \mathrm{H}-11 / \mathrm{H}-12$ and of $\mathrm{H}-14 / \mathrm{H}-15$ confirmed the above deduction. The stereochemistry of compound $\mathbf{1}$ was presumed to be as shown (as Figure 2) on the basis of the ROESY cross peaks from H-7 $\left(\delta_{\mathrm{H}} 1.34\right)$ to $\mathrm{H}-17\left(\delta_{\mathrm{H}} 0.86\right)$ and $\mathrm{H}-18\left(\delta_{\mathrm{H}} 0.84\right)$ and from $\mathrm{H}-6\left(\delta_{\mathrm{H}} 1.07\right)$ and $\mathrm{H}-5\left(\delta_{\mathrm{H}} 1.54\right)$ to $\mathrm{H}-16\left(\delta_{\mathrm{H}} 0.87\right)$. Additionally, their almost identical chemical shifts of $\mathrm{C}-5-\mathrm{C}-7$ and C-18 also supported this deduction. Detailed examination of the ${ }^{13} \mathrm{C}$ NMR data of C-12-C-15 and $\mathrm{C}$-20 suggested that compound $\mathbf{1}$ had the same E-configuration of the double bond at $\mathrm{C}-13$ as cassipourol [9], which was confirmed by the ROESY connections of $\mathrm{CH}_{3}-20\left(\delta_{\mathrm{H}} 1.71\right)$ and $\mathrm{H}-15\left(\delta_{\mathrm{H}}\right.$ 4.68), and of $\mathrm{H}-12\left(\delta_{\mathrm{H}} 2.01\right)$ and $\mathrm{H}-14\left(\delta_{\mathrm{H}} 5.36\right)$. Consequently, the structure of 1 was established as cassipouryl formate. The biosynthetic pathway of diterpenoids 1-4 was discussed as the reference [10] (Figure 3). 
Table 1. ${ }^{1} \mathrm{H}$ NMR and ${ }^{13} \mathrm{C}$ NMR data for compounds $1-4(\delta \text { in ppm })^{\mathrm{a}}$.

\begin{tabular}{cccccc}
\hline & \multicolumn{1}{c}{$\mathbf{1}$} & \multicolumn{2}{c}{$\mathbf{1}$} \\
\cline { 2 - 6 } No & $\boldsymbol{\delta}_{\mathbf{H}}$ & $\boldsymbol{\delta}_{\mathbf{c}}$ & $\mathbf{N o}$ & $\boldsymbol{\delta}_{\mathbf{H}}$ & $\boldsymbol{\delta}_{\mathbf{C}}$ \\
\hline 1 & & 36.6 & 12 & $2.01 \mathrm{~m}, 1.14 \mathrm{~m}$ & 39.8 \\
2 & $1.14 \mathrm{~m}$ & 39.4 & 13 & & 143.8 \\
3 & $1.38 \mathrm{~m}$ & 24.8 & 14 & $5.36 \mathrm{td}(7.2$, & 117.3 \\
4 & $1.26 \mathrm{~m}$ & 37.3 & 15 & $4.68 \mathrm{~d}(7.2)$ & 60.8 \\
5 & $1.54 \mathrm{~m}$ & 27.9 & 16 & $0.87 \mathrm{~s}$ & 22.7 \\
6 & $1.07 \mathrm{~m}$ & 32.8 & 17 & $0.86 \mathrm{~s}$ & 22.6 \\
7 & $1.20 \mathrm{~m}, 1.34$ & 24.5 & 18 & $0.84 \mathrm{~d}(6.6)$ & 19.7 \\
8 & $1.38 \mathrm{~m}$ & 37.3 & 19 & $0.85 \mathrm{~d}(6.6)$ & 19.8 \\
9 & $1.38 \mathrm{~m}$ & 32.7 & 20 & $1.71 \mathrm{~s}$ & 16.4 \\
10 & 1.26 & 37.4 & 1 & $8.07 \mathrm{~s}$ & 161.1 \\
11 & $1.38 \mathrm{~m}, 1.45$ & 25.0 & & & \\
\hline${ }^{\mathrm{a}}{ }^{1} \mathrm{H}$ NMR and ${ }^{13} \mathrm{C}$ NMR Data for $\mathbf{1}$ in $\mathrm{CDCl}_{3}$ at $600 \mathrm{MHz}$ and $150 \mathrm{MHz}$, respectively.
\end{tabular}

The known compounds were assigned as cassipourol (2) [9], 4',5'-dehydrodiodictyonema (3) [11], acetyl incensole (4) [12], aromadendrane- $4 \beta, 10 \beta$-diol (5) [13], (-)-globulol (6) [14], spathulenol (7) [15], $3 \beta, 6 \beta, 8 \alpha, 10 \beta$-tetramethylwiddrane-2(3)-en-10 $\alpha$-ol (8) [16], and $\alpha$-cadinol (9) [17] according to their NMR and MS data as well as the comparison with the reported values.

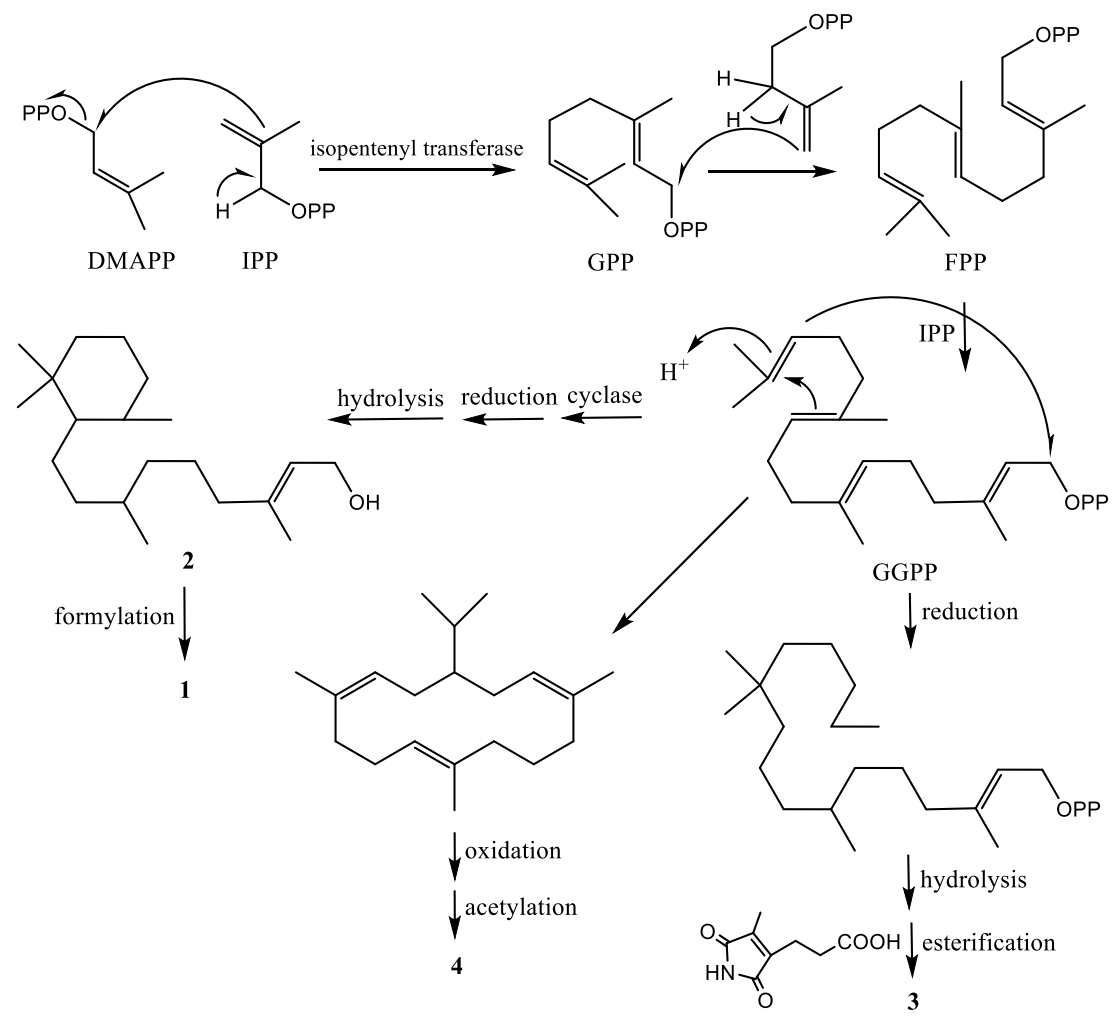

Figure 3. Biosynthetic pathway for compounds 1-4.

In summary, one new monocyclic diterpenoid, together with three known diterpenoids and five sesquiterpenoids were isolated from the twigs and leaves of $S$. fluviatile. This was the first examples for the chemical constituents of S. fluviatile and the first report on the diterpenoids of genus Syzygium. 
This discovery provided new evidences not only for the chemical diversity of the genus Syzygium, but also for the chemotaxonomic makers of $S$. fluviatile.

\section{Acknowledgments}

This work was financially supported by the National Natural Science Foundation of China (No. 31560098).

\section{Supporting Information}

Supporting Information accompanies this paper on http://www.acgpubs.org/journal/recordsof-natural-products

\section{ORCID}

Dingli Zhang: 0000-0002-9073-6761

Yikao Hu: 0000-0002-3616-8556

Li Wang: 0000-0002-7004-4725

Shengxiong Huang: 0000-0002-3616-8556

Yan Zhao: 0000-0002-1638-7751

Mengjia Li: $0000-0002-7454-3767$

Feng Li: 0000-0002-3943-5058

Yong Zhao: $\underline{0000-0002-3996-2480}$

\section{References}

[1] L. W. Tian, M. Xu, D. Wang, H. T. Zhu, C. R. Yang and Y. J. Zhang (2011). Phenolic constituents from the leaves of Syzygium forrestii Merr. and Perry, Biochem. Syst. Ecol. 39, 156-158.

[2] G. Q. Li, Y. B. Zhang, P. Wu, N. H. Chen, Z. N. Wu, L. Yang, R. X. Qiu, G. C. Wang and Y. L. Li (2015). New phloroglucinol derivatives from the fruit tree Syzygium jambos and their cytotoxic and antioxidant activities, J. Agric. Food Chem. 63, 10257-10262.

[3] T. Manaharan, D. Appleton, H. M. Cheng and U. D. Palanisamy (2012). Flavonoids isolated from Syzygium aqueum leaf extract as potential antihyperglycaemic agents, Food Chem. 132, 1802-1807.

[4] F. F. Liu, T. Yuan, W. Liu, H. Ma, N. P. Seeram, Y. Y. Li, L. Xu, Y. Mu, X. S. Huang and Y. L. Li (2017). Phloroglucinol derivatives with protein tyrosine phosphatase 1B inhibitory activities from $E u$ -genia jambolana seeds, J. Nat. Prod. 80, 544-550

[5] Y. K. Hu, L. Wang, Y. Y. Li, M. J. Li, W. Xu, Y. Zhao, F. Li and Y. Zhao (2018). Five new triterpenoids from Syzygium samarangense (B1.) Meer. et Perry, Phytochemistry Lett. 25, 147-151.

[6] S. H. Xu, W. Xu, L. Wang, Y. K. Hu, J. P. Liu, Y. Zhao, M. J. Li, F. Li, S. X. Huang and Y. Zhao (2018). New phloroglucinol derivatives with protein tyrosine phosphatase 1B (PTP1B) inhibitory activities from Syzygium austroyunnanense, Fitoterapia 131, 141-145.

[7] T. Manaharan, D. Appleton, H.M. Cheng and U.D. Palanisamy (2012). Flavonoids isolated from Syzygium aqueum leaf extract as potential antihyperglycaemic agents, Food Chem. 132, 1802-1807.

[8] J. Chen (1984). Flora of China. Vol 53 (1). Beijing: Science Press, pp. 72.

[9] V. S. P. Chaturvedula, A. Norris, J. S. Miller, F. Ratovoson, R. Andriantsiferana, V. E. Rasamison and D. G. I. Kingston (2006). Cytotoxic diterpenes from Cassipourea madagascariensis from the Madagascar rainforest, J. Nat. Prod. 69, 287-289.

[10] N. Shimizua, D. Sakataa, E. A. Schmelzb, N. Moric and Y. Kuwaharad (2017). Biosynthetic pathway of aliphatic formates via a Baeyer-Villiger oxidation in mechanism present in astigmatid mites, PNAS, 114, 2616-2621.

[11] P. Yang, D. Q. Liu, T. J. Liang, J. Li, H. Y. Zhang, A. H. Liu, Y. W. Guo and S. C. Mao (2015). Bioactive constituents from the green alga Caulerpa racemosa, Bioorg. Med. Chem. 23, 38-45.

[12] F. Wang, Z. L. Li, T. Liu and H. M. Hua (2009). Cembrane diterpenes in olibanum, China J. Chin. Mater. Med. 34, 2477-2480.

[13] I. C. Moreira, J. H. G. Lago, M. C. M. Young and N. F. Roque (2003). Antifungal aromadendrane sesquiterpenoids from the leaves of Xylopia brasiliensis, J. Brazil. Chem. Soc. 14, 828-813. 
[14] J. Wang, J. J. Xu, W. Qiao and S. A. Tang (2016). Chemical constituents from fruits of Eucalyptus globulus, Chin. Tradit. Herb. Drugs 47, 4336-4339.

[15] P. Du, Z. R. Hu-Yang, W. C. Zhang and G. B. Xie (2017). Study on chemical constituents of Uvaria grandiflora, China Med. Herald. 14, 20-22.

[16] T. Muhammad, S. Deny and F. R. Mohamad (2013). A new sesquiterpene from Knema patentinervia, Chem. Nat. Compd. 48, 985-987.

[17] M. L. D. Miranda, F. R. Garcez, A. R. Abot and W. S. Garcez (2014). Sesquiterpenes and other contituents from leaves of Pterodon pubescens Benth (Leguminosae), Quím. Nova 37, 473-476.

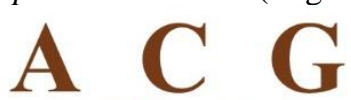

publications

2020 ACG Publications 